\title{
Employing Constructed Wetlands to Sustainably Manage Nutrient-Bearing Water: A Review with an Emphasis on Soil Behavior and Effluent Nutrient Reduction
}

\author{
Michael Aide*, Indi Braden, Sven Svenson, Samantha Siemers, Susan Murray \\ Department of Agriculture, Southeast Missouri State University, Cape Girardeau, USA \\ Email: *mtaide@semo.edu
}

How to cite this paper: Aide, M., Braden, I., Svenson, S., Siemers, S., \& Murray, S. (2020). Employing Constructed Wetlands to Sustainably Manage Nutrient-Bearing Water: A Review with an Emphasis on Soil Behavior and Effluent Nutrient Reduction. Journal of Geoscience and Environment Protection, 8, 94-106.

https://doi.org/10.4236/gep.2020.89006

Received: August 5, 2020

Accepted: September 12, 2020

Published: September 15, 2020

Copyright $\odot 2020$ by author(s) and Scientific Research Publishing Inc. This work is licensed under the Creative Commons Attribution International License (CC BY 4.0).

http://creativecommons.org/licenses/by/4.0/

\begin{abstract}
Constructed wetlands are engineered structures designed to simulate processes of natural wetlands to mitigate anthropogenic organic and inorganic materials to shelter soil and water resources. This review focuses on the global interest in constructed wetland application to sustain soil health and water quality and water abundance. Engineering criterion remains a function of nutrient chemistry and load with suitability factors including the local soil and hydrogeology constraints, climate, vegetation selection, the degree of required influent improvement, and reactor types and sizes. Future research needs to focus on: 1) reactor designs criteria, 2) the biology of the microbial community, 3) selection criteria for native vegetation, and 4) criteria to reapply treated water to foster land productivity, especially for region's experiencing water deficiencies.
\end{abstract}

\section{Keywords}

Wetlands, Nitrogen, Phosphorus, Water Quality, Constructed Wetland Engineering Criteria

\section{Protecting Freshwater Resources with Constructed Wetlands}

Constructed treatment wetlands are routinely termed "engineered wetlands" or "constructed wetlands". Constructed wetlands operate by optimizing hydrological, biological, and geochemical processes instrumental to healthy wetland ecosystems, including those processes associated with aquatic plants, hydric soils, 
and microbial assemblages, to improve water quality. When properly designed and installed, constructed wetlands permit soils to acquire the hydrological, biological, and geochemical wetland processes responsible for the proper functioning of naturally-occurring and pristine wetlands. Perceived advantages of the constructed wetland include: 1) on-site nutrient reductions $\left(\mathrm{NH}_{4}-\mathrm{N}\right.$, organic- $\mathrm{N}$, $\mathrm{NO}_{3}-\mathrm{N}$, total $\mathrm{P}, \mathrm{PO}_{4}-\mathrm{P}$, biological oxygen demand (BOD), chemical oxygen demand (COD)) and corresponding adjacent water quality improvements, 2) odor reductions, 3) wildlife enhancements, 4) aesthetics, and 5) potential economic benefits (United States Department Agriculture, Natural Resources Conservation Service, 2009).

Constructed wetlands have been studied to determine their effectiveness in reducing nutrient availability, particularly dairy and swine wastewater (United States Department Agriculture, Natural Resources Conservation Service, 2009; Reedyk et al., 2017; White, 2013). Constructed wetland design criteria usually involve consideration of 1) location analysis to avoid negative environmental impacts associated with groundwater quality and flooding, 2) size considerations to address expected water volumes and their nutrient loads, 3) layout analysis featuring the number of cells and their length to width ratio, 4) inflow/outflow controls, 5) vegetation, 6) wildlife management, and 7) post-wetland effluent options. The effectiveness of constructed wetlands is predicated on their design; however, improved biological and hydrological indicators are desired to better understand how different engineered designs perform (Reedyk et al., 2017). On average, nutrient concentration reductions in reviewed studies suggest: 1) ammonia reductions of $42 \%$ to $99 \%$, 2) total nitrogen reductions of $44 \%$ to $92 \%, 3$ ) reductions of biological oxygen demands of $39 \%$ to $99 \%$, and 4) a median reduction of phosphorus at $45 \%$ (Reedyk et al., 2017). Thus, the literature supports the premise that constructed wetlands limit nutrient transport.

This research review conveys the need for adopting engineered constructed wetlands where soil, water and air quality may be degraded by selected anthropogenic activities. Constructed wetlands are designed to facilitate an integrated climate-adjusted system where water, soil, animal waste and other forms of nutrient migration can positively interact to sustain or improve environmental resources.

\section{Constructed Wetland Efficacy}

The literature addresses the efficacy of well-designed wetlands to 1) protect freshwater resources, 2) limits nutrient migration from stockpiled livestock manure, and 3) effectively purifies storm runoff and urban wastewater. Ouyang (2013), in Mississippi, compared constructed wetlands and constructed ponds receiving storm waters for their influence on shallow groundwater quality. Monitoring wells showed that groundwater phosphorus concentrations decreased after construction of the constructed wetlands, but increased for constructed ponds. Groundwater total nitrogen and ammonium-N exhibited greater groundwater concentrations after installation of both constructed wetlands and constructed 
ponds.

In the Netherlands, Meers et al. (2008) developed a sequential system wherein pig manure was first separated into liquid and solid fractions with subsequent conversion of the solid fraction into a commercial product, and reduction of the nutrient content of the liquid fraction using constructed wetlands. These authors showed wetland effluent discharges having nitrogen concentrations smaller than the threshold of $2 \mathrm{mg} \mathrm{N} \mathrm{L}^{-1}$ and the chemical oxygen demand concentrations were smaller than $125 \mathrm{mg} \mathrm{COD} \mathrm{L}^{-1}$. In Spain, Munoz et al. (2016) addressed national concerns involving environmental issues associated with pig manure. These authors investigated different hydraulic retention times of three and seven days to estimate the optimum conditions for constructed wetlands to purify pig slurry. Greater removal rates for total phosphorus, Kjeldahl N, chemical oxygen demand, ammonium and nitrate were observed for the longer seven-day retention time, demonstrating that there exists the need for sufficient time to attain system equilibration.

Hunt et al. (2003) assessed swine manure wastewater treatment using constructed wetlands with the expressed goal of determining denitrification rates and denitrification enzyme activity. In their project, two sequential wetlands were installed in series and planted with either 1) rushes and bulrushes or 2) bur-reeds and cattails. Denitrification enzyme activity was greater in the rushes and bulrushes community $\left(0.52 \mathrm{mg} \mathrm{N} \mathrm{kg}\right.$-soil $\left.{ }^{-1} \cdot \mathrm{h}^{-1}\right)$ than for the bur-reed and cattail community $\left(0.21 \mathrm{mg} \mathrm{N} \mathrm{kg-soil}{ }^{-1} \cdot \mathrm{h}^{-1}\right)$. Denitrification enzyme activity increased with greater nitrogen accumulation. The denitrification enzyme activity was equivalent to $9.55 \mathrm{~kg} \mathrm{~N} \mathrm{ha}^{-1} \cdot \mathrm{d}^{-1}$. Water depth within the constructed wetlands was important for maintaining anaerobic soil conditions and optimizing denitrification

In China, Lu et al. (2009) observed the effectiveness of a free water surface constructed wetland in reducing total nitrogen and ammonium. Total nitrogen and ammonium were effectively reduced upon wetland passage; however, the system effectiveness was influenced by the hydrologic loading rate, the inflow nitrogen concentration and temperature (seasonality). The hydrologic retention rate was inversely related to the nitrogen wetland recovery. Also, in China, Jia et al. (2016) presented a field monitoring study for a constructed wetland having a series of five cells receiving water from an impacted river. The hydrologic budget demonstrated that $18.4 \%$ of the inflow was lost to seepage and increased evapotranspiration. The wetlands retained $99 \%$ of the total suspended solids, $61 \%$ of the total phosphorus, and $54 \%$ of the total nitrogen. In an aridregion, the loss of influent water to seepage and increased evapotranspiration needs to be appropriately coupled with the wetland's nutrient sequestration.

In Florida, Sigua et al. (2006) observed soil profile phosphorus and other nutrients in a beef cattle pasture after 63 years post-wetland conversion. Adjacent wetlands with similar soils were employed for reference. These authors documented that the beef cattle pasture soils possessed 1) a decrease in total organic carbon, total nitrogen, potassium and 2) an increase in $\mathrm{pH}$, calcium, magnesium, 
manganese and iron. Phosphorus was sequentially fractionated into Al-P, CaMg-P, FeMn-P and organic-P fractions, with the wetland soils having greater whole soil profile P concentrations. Scholz and Hedmark (2010) observed the establishment of Phragmites australis (Cav.) Trin. Ex Steud in a constructed vertical flow wetland treated with organic matter enriched urban runoff to quantify changes in nitrogen and chemical oxygen demand. The presence of established vegetation supported nitrogen removal and reduced chemical oxygen demands compared to the unplanted control.

In India, Thalla et al. (2019) compared constructed horizontal and vertical flow wetlands with each having two hydraulic retention times. The vertical flow constructed wetland demonstrated better overall efficiencies for lowering 1) the biological and chemical oxygen demands and 2) the ammonium, nitrate, and phosphate concentrations. Reduction in the biological oxygen demand was attributed to the microbial communities, especially those microbial communities associated with the root rhizosphere. The presence of humic substances in the influent water supported greater chemical oxygen demand values. The effect of greater hydraulic retention times ( 24 vs 12 hours) supported a greater reduction in biological and chemical oxygen demands and reduced nitrogen species concentrations.

In Ethiopia, Assefa et al. (2019) conducted a nitrogen reduction evaluation of an anaerobic digester-aerobic reactor sequence coupled in sequence with a horizontal subsurface flow constructed wetland. The anaerobic digester removed $67 \%$ of the oxidized nitrogen, with further removal by the aerobic reactor. Effluent returned to the environment was shown to have a removal efficiency of $82 \%$ for nitrate and $88 \%$ for ammonium. The authors proposed that adding methanol, sugars and volatile fatty acids to provide additional mineralizable carbon for microbial activity may improve the nitrogen removal efficiency. In Pakistan, Ali et al. (2018) evaluated the treatment efficiency of a hybrid constructed wetland receiving municipal wastewater and considered the usefulness of the treated water for agricultural irrigation. The hybrid constructed wetland consisted of a vertical flow constructed wetland and a series of five treatment ponds having aquatic plants. Treatment efficiency percentages were: $57 \%$ for electrical conductivity, $57 \%$ for total dissolved solids, $68 \%$ for biological oxygen demand, and $64 \%$ for chemical oxygen demand.

In India, Kumar and Dutta (2019) provided a review of constructed wetland microcosms to investigate the performance of various supporting media, vascular vegetation and microorganisms for wastewater treatment. The $\mathrm{pH}$, dissolved oxygen, and temperature were the essential environmental state factors, whereas the hydraulic loading rate, hydraulic retention time, macrophyte diversity, supporting media, and water depth were important design criteria affecting system performance. Their review of the literature supported the need for system aeration and re-circulation of the effluent water back through the system for optimal system performance.

In China Wang et al. (2018) performed a review of radial oxygen loss in the 
rhizosphere of macrophytes to assess its influence on contaminant removed in constructed wetlands. The authors classified plants as 1) emerging, 2) floating and 3) submerged. Within each plant classification, the radial oxygen loss varied from 20 to in excess of $300 \mu \mathrm{mol}$ oxygen daily per root dry mass. The amount of oxygen released to the rhizosphere was related to plant anatomy (example-leaf surface area), the rate of photosynthesis, the rate of root respiration, and other factors. The oxygen release rate to the rhizosphere influences the population relationships involving aerobic and anaerobic prokaryotes, thus subsequently influencing mineralization and organic matter decomposition, nitrification, and denitrification reactions.

Jesus et al. (2018) reviewed on the influence of plant performance in constructed vertical and horizontal subsurface flow wetlands. Comparison of previous research was compromised by inadequate descriptions of research designs, statistical analysis, and the plant nutrient uptake capacity when the influent wastewater nutrient levels varied. Carvalho et al. (2017) provided a meta-analysis on recent developments of constructed wetlands. The authors noted that constructed wetlands are being developed to address an ever-increasing array of environmental issues, including persistent organic pollutants, polychlorinated biphenyls, organochlorine pesticides, pharmaceuticals, and personal care products. Tai et al. (2018), in China, investigated iron plaque formation on wetland plant roots and noted their importance in the deactivation of antibiotic transport.

Bai et al. (2016) investigated a multilayer substrate design for horizontal subsurface flow constructed wetlands to assess its performance in supporting nutrient removal. Using Modflow (a groundwater simulation software package), three constructed wetland systems employed tracers to evaluate hydraulic performance and track the spatial distribution within each constructed wetland to determine if preferential flow paths were reducing nutrient removal efficiencies. Multilayer substrates significantly improved nutrient removal when compared to a monolayer design, a feature attributed to reducing preferred flow pathways and the avoidance of zones not actively interacting with the wastewater. Hang et al. (2016) reviewed the influence of carbon source addition to aid the denitrification performance of constructed wetlands. The authors concluded that bioavailable carbon sources effectively improved denitrification; however, information concerning dosage and appropriate C:N ratios is limited. Huang et al. (2013) reviewed the mechanisms and environmental factors influencing nitrous oxide emissions. The release of $\mathrm{N}_{2} \mathrm{O}$ from constructed wetlands has been reported to range from -16.7 to $188 \mathrm{mg} \mathrm{N} \mathrm{N} \mathrm{m}^{-2}$. day $^{-1}$. Nitrous oxide production arises in association with nitrification, denitrification, nitrifier denitrification and nitrate-ammonium reactions. Dissolved oxygen in wastewater affects nitrification and denitrification reactions, thus $\mathrm{N}_{2} \mathrm{O}$ emission. Aquatic plants, the flow regime, the oxidation-reduction status, nitrate concentration, the $\mathrm{C}: \mathrm{N}$ ratio and other factors are intricately coupled in regulating $\mathrm{N}_{2} \mathrm{O}$ emissions. Erler and Eyre (2010) employed stable isotope signatures to quantity nitrogen processes in constructed wetlands. The maximum rate of denitrification was estimated to be 956 
$\pm 187 \mu \mathrm{mol} \cdot \mathrm{m}^{-2} \cdot \mathrm{h}^{-1}$ and the maximum nitrification rate was $182 \pm 28.9 \mu \mathrm{mol} \cdot \mathrm{m}^{-2} \cdot \mathrm{h}^{-1}$.

\section{Vegetation Selection}

Vegetation selection needs to be appropriate for the constructed wetland, with anticipation that seasonal water levels will vary from the presence of ponded water (anaerobic soil conditions) to partial soil drying (suboxic to oxic soil conditions). The vegetation selection necessitates that plant diversity is important, relying on a diversity of native and locally obtained species. Furthermore, locally-adapted plant species should be selected for water quality and wildlife habitat functions. Table 1 lists a partial plant species list suitable for constructed wetlands.

Table 1. Potential plant selections.

\begin{tabular}{|c|c|c|}
\hline Common Name & Genus and Species & Type of Plant \\
\hline Serviceberry, juneberry & Amelanchier arborea & tree; emergent woody \\
\hline pawpaw & Asimina triloba & tree; emergent woody \\
\hline pale purple coneflower & Echinacea pallida & herbaceous perennial \\
\hline purple coneflower & Echinacea purpurea & herbaceous perennial \\
\hline rose mallow & Hibiscus lasiocarpos & herbaceous perennial \\
\hline swamp mallow & Hibiscus moscheutos & herbaceous perennial \\
\hline possumhaw & Ilex decidua & deciduous shrub \\
\hline dwarf crested iris & Iris cristata & herbaceous perennial \\
\hline copper iris & Iris fulva & herbaceous perennial \\
\hline rush; common rush & Juncus effusus & emergent herbaceous \\
\hline rush; hard rush; blue rush & Juncus inflexus & emergent herbaceous \\
\hline tupelo gum & Nyssa aquatica & tree; emergent woody \\
\hline black gum & Nyssa sylvatica & tree; emergent woody \\
\hline common reed & Phragmites australisamericanus & emergent herbaceous \\
\hline Sullivant's coneflower & Redbeckia fulgida var. sullicantii & herbaceous perennial \\
\hline broadleaf arrowhead & Sagittaria latifolia & herbaceous perennial \\
\hline green bulrish & Scirpus atrovirens & emergent herbaceous \\
\hline woolgrass, bulrush & Scirpus cyperinus & emergent herbaceous \\
\hline meadowsweet & Spiraea alba & deciduous shrub \\
\hline bald cypress & Taxodium distichum var. distichum & tree; emergent woody \\
\hline broadleaf cattail & Typha latifolia & emergent herbaceous \\
\hline arrowwood viburnum & Viburnum dentatum & deciduous shrub \\
\hline blackhaw viburnum & Viburnum prunifolium & deciduous shrub \\
\hline southern wild rice & Zizania aquatica & emergent herbaceous \\
\hline giant cutgrass & Zizaniopsis miliacea & emergent herbaceous \\
\hline
\end{tabular}


Emergent herbaceous plants are the most common plant species selected for constructed wetlands used for waste treatment. Emergent herbaceous plants are rooted in soil and have stems with leaves that emerge above the water surface. Typical plants include: bulrush (Scirpus spp.), cattail (Typha spp.), common reed (Phragmites), giant cutgrass (Zizaniopsis spp.), and rush (Juncus spp.). These vascular wetland plants have aerenchyma or aerenchymous tissues that facilitate atmospheric oxygen movement to roots and rhizomes to support root respiration. Aerenchymas tissues contain lacunae, which is a network of hollow tubes and lenticels that transverse the stem and roots, permitting gaseous exchange. Emergent macrophytes mainly result in nutrient and other pollutant reductions; however, important corollary aspects include: 1) providing a substrate to support beneficial microbial growth, 2) facilitating nitrification $\left(\mathrm{O}_{2}\right.$ generator) and denitrification, 3) influencing water and pollutant transport, 4) filtering nutrient-rich solids to encourage settling in the wetland, 5) providing source of shade to reduce excessive water temperatures, and 6) permitting a more robust deposition of inorganic and organic materials to support soil/sediment accretion and subsequent soil formation. Establishing plant species that maintain physiological activity during cold temperatures is important for winter functionality (Wang et al., 2016).

\section{Soil Processes}

Soil processes critical to the optimization of constructed wetland waste treatment include key components associated with the carbon, nitrogen, and phosphorus cycles (Essington, 2004). Figure 1 shows the constructed wetland partitioning into atmosphere, water and soil spheres. As expected, vegetation resides in the soil, water and atmosphere spheres.

Carbon cycle pathways important to constructed wetlands include: 1) plant growth and development as a result of photosynthesis and respiration, 2) microbial facilitate dimmobilization and mineralization of soil organic materials, and 3) human modifications, such as biomass harvesting. The nitrogen and phosphorus cycles are intimately inter-connected with the carbon cycle. For example, the microbial directed mineralization of soil organic matter results in the in creased ammonium, phosphate and sulfate availability.

Key components of the nitrogen cycle are advanced in well-designed constructed wetlands. Denitrification in suboxic to anoxic soil environments is integral to reducing nitrate- $\mathrm{N}$ concentrations. Biological nitrogen fixation and mineralization

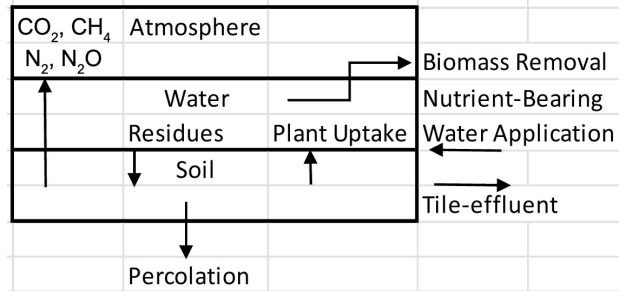

Figure 1. Illustration of nutrient pathways in an idealized constructed wetland. 
are more evident in oxic environments. Nitrification is a nitrogen pathway involving the microbial mediated conversion of ammonium $\left(\mathrm{NH}_{4}^{+}\right)$to nitrate $\left(\mathrm{NO}_{3}^{-}\right)$. Ammonium is converted to nitrite $\left(\mathrm{NO}_{2}^{-}\right)$according to:

$$
2 \mathrm{NH}_{4}^{+}+3 \mathrm{O}_{2}=2 \mathrm{NO}_{2}^{-}+4 \mathrm{H}^{+}+2 \mathrm{H}_{2} \mathrm{O}+\text { Energy }
$$

The aerobic bacteria Nitrosomonas is the primary microorganism responsible for the oxidation of ammonium. Subsequently, Nitrobacter facilitates the rapid oxidation of nitrite to nitrate:

$$
2 \mathrm{NO}_{2}^{-}+\mathrm{O}_{2}=\mathrm{NO}_{3}^{-}
$$

The entire process may be completed within three days if the soil moisture is near $60 \%$ of field capacity and the soil temperature approaches $30^{\circ} \mathrm{C}$ (Essington, 2004).

In constructed wetlands, the processes of mineralization and nitrification are inhibited because of restricted oxygenation of the rooting zone; however, mineralization and nitrification will occur at reduced intensities if sufficient oxygen diffuses from the atmosphere through the shallow water column and partially oxidizes the upper several centimeters of soil (Figure 2). Additionally, emergent herbaceous plants may effectively support a more oxic soil environment in the root rhizosphere. Thus, constructed wetlands may foster alternating nitrification and denitrification episodes with fluctuating oxic-anoxic soil environments. With prolonged and intense anaerobic conditions sulfate reduction and methane $\left(\mathrm{CH}_{4}\right)$ production likely prevails.

Denitrification is the microbial reduction of nitrate to $\mathrm{N}_{2}, \mathrm{NO}$ or $\mathrm{N}_{2} \mathrm{O}$ during periods of extreme soil wetness. The process is conducted by anaerobic bacteria according to half-cell reaction:

$$
2 \mathrm{NO}_{3}^{-}+12 \mathrm{H}^{+}+10 \mathrm{e}^{-}=\mathrm{N}_{2}+6 \mathrm{H}_{2} \mathrm{O}
$$

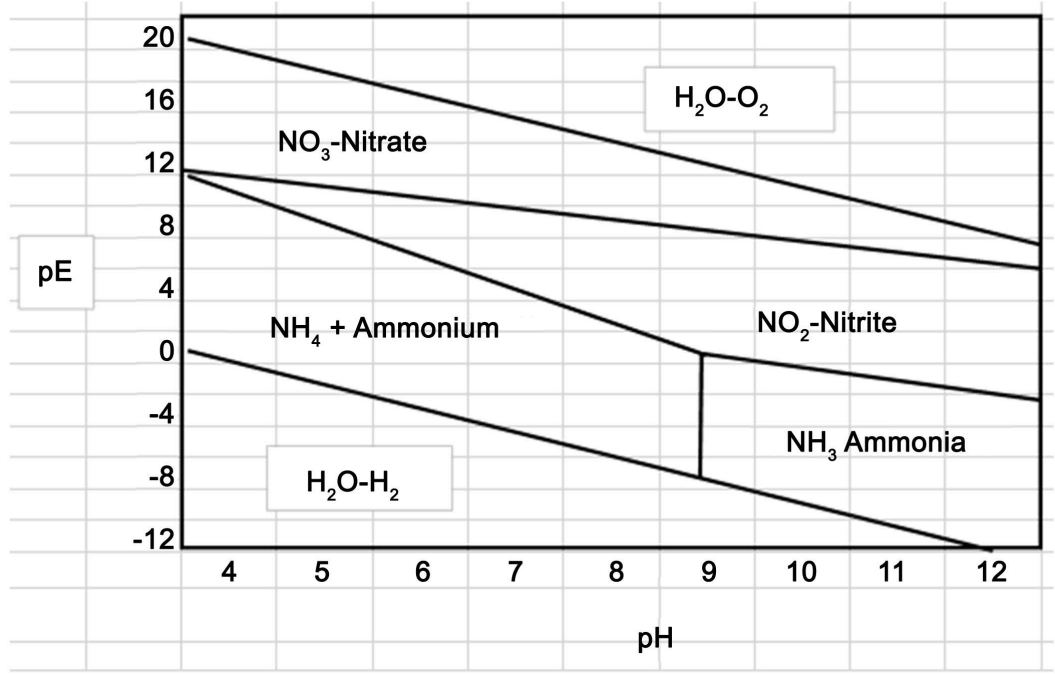

Figure 2. A Pourbaix diagram illustrating where selected nitrogen species are expected to be the dominant species based on acid-base and oxidation-reduction reactions (constructed by the authors). 
Denitrification occurs in warm, anaerobic (suboxic to anoxic) soil conditions. Denitrification is inhibited at soil temperatures greater than $60^{\circ} \mathrm{C}$ and at or below $4^{\circ} \mathrm{C}$. Facultative aerobic bacteria (Pseudomonas, Bacillus and Paracoccus) and autotropic bacteria (Thiobacillus denitrificans and Thiobacillus thioparus) are largely responsible for the denitrification process. At $\mathrm{pH}$ levels greater than six, $\mathrm{N}_{2}$ is the dominant denitrification bi-product; however, at $\mathrm{pH}$ levels more acid than $\mathrm{pH}$ 5.5, nitric oxide (NO) is the dominant denitrification product. At an intermediate $\mathrm{pH}$ interval between $\mathrm{pH} 5.5$ and $\mathrm{pH} 6$, nitrous oxide $\left(\mathrm{N}_{2} \mathrm{O}\right)$ is the dominant denitrification bi-product (Essington, 2004).

Plant uptake of ammonium, nitrate, phosphate and other plant essential nutrients results in increased plant growth and development that may be harvested for fiber and animal forage. Plant materials may also be incorporated into the soil for partial decomposition and the creation of an organic-rich (histic) epipedon.

In Nevada, Chavan and Dennett (2008) developed a wetland water quality model to evaluate nitrogen, phosphorus and sediment retention in constructed wetlands. The model was constructed with four submodels: 1) hydrological, 2) nitrogen, 3) phosphorus, and 4) sediment. The model was calibrated from data obtained from an experimental wetland and accurately predicted wetland retention of nitrogen (62\%), phosphorus (38\%), and sediment (84\%). The total suspended solids submodel is predicated on net settling, with net settling a function of particle settling, burial, and sediment resuspension. The nitrogen submodel estimates 1) volatilization, 2) mineralization, 3) nitrification, 4) denitrification, 5) plant uptake and translocation, 6) particle settling and resuspension, and 7) diffusion. Yuan et al. (2020) very recently provided a detailed and compelling review of constructed wetland modelling.

\section{Effectively Purifying Storm Runoff, Urban Wastewater and Livestock Wastewater with Constructed Wetlands}

Runoff originating from livestock confinement areas and collected in holding ponds can frequently be used as an irrigation source (Reedyk et al., 2017). Total ammonia concentrations in the pretreated wastewater entering livestock constructed wetlands are nearly always greater than $20 \mathrm{mg} \mathrm{NH}_{4} / \mathrm{L}$ and often will exceed $100 \mathrm{mg} \mathrm{NH} / / \mathrm{L}$. At any ammonia concentrations above $20 \mathrm{mg} \mathrm{NH}_{4} / \mathrm{L}$, the ammonia volatilization process becomes important, resulting in odor issues. Most pretreated livestock wastewaters discharged to treatment wetlands are typically anaerobic, which means that nitrification in the surface flow will be limited and any subsequent denitrification will also be limited (Ouyang, 2013). Constructed wetland is a treatment component of an animal waste management system because its purpose is to reduce pollution potential of wastewater; however, discharge of treated livestock wastewater is not usually a viable option, due to state restrictions (Payne et al., 1996; Payne \& Knight, 1997; USEPA, 1995). Similarly, Payne et al. (1996), Miller et al. (1996), and Hughes et al. (1996) illustrate the usefulness of constructed wetlands in facilitating removal for biological oxy- 
gen demand, fecal bacteria and nitrogen. Odor levels are potentially lower in wetlands as compared to lagoons or storages pond wastes due to effluent levels (Reedyk et al., 2017). Water pH remains a factor influencing odor and volatilization. Thus, constructed wetlands reduce the total nutrient load that egresses from the production unit and allows for less land area dedicated towards soil application. Of pragmatic importance, producer time and financials on manure management and land irrigation are augmented.

We present our designed constructed wetland to illustrate small landholder suitability (Figure 3). Beef cattle manure from a small confined feed facility (50 head) is mechanically transferred to a tall fescue hayfield ( $3 \mathrm{ha}$ ) for application. Rainwater runoff transfers nutrient and suspended manure via a grass waterway to a constructed wetland ( $2 \mathrm{ha}$ ). Water effluent from the constructed wetland is managed using stoplog boxes that act to retain water until irrigation onto a crop production field is desired. The system stores rainwater until desired for irrigation and the vegetated constructed wetland sequesters nitrogen and phosphorus. Vegetation harvested from the wetland is composed as a soil amendment. Constructed wetlands are also suitable for treating urban runoff, storm water flows and household effluents.

\section{Conclusion with an Emphasis on Future Needs and Research}

Constructed wetlands provide a global agriculture interest in sustainable soil health and foster water conservation and water quality improvements. If properly designed, constructed wetlands impose and optimize the biological, chemical, and physical processes of natural wetland ecosystems and efficiently remove contaminants and excessive nutrient loads. Constructed wetlands may have the advantage of being low maintenance and affordable, reduce odor, support the re-introduction of purified water, and provide long-term soil health development.

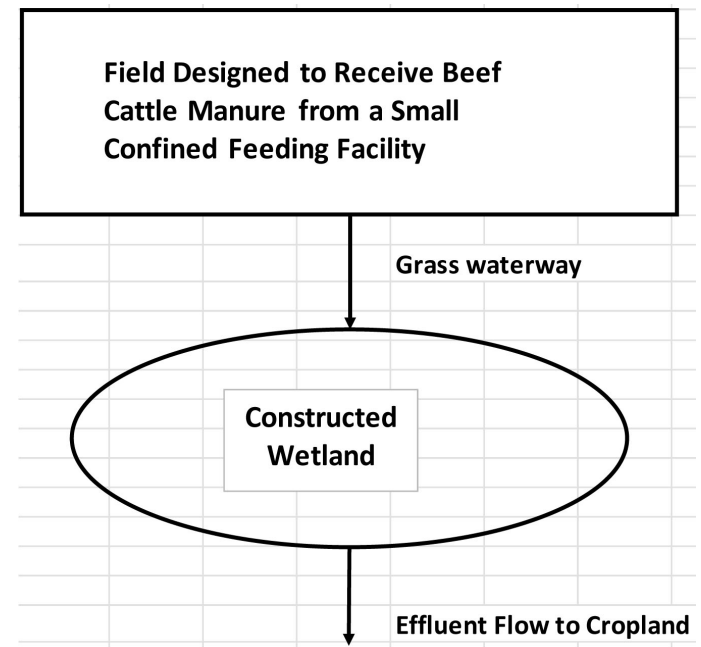

Figure 3. Illustration of the designed constructed wetland at the David M. Barton Agriculture Research Center at Southeast Missouri State University. 
Future research needs are as varied as the multitude of nations that have investigated constructed wetlands. Future research must consider enhancing constructed wetland design to anticipate the nutrient load and the ability to maintain these engineered systems. Specific research goals include: 1) reactor designs that account for the nutrient loads and water volumes expected for a 10-year event, 2) providing environmental conditions and carbon sources to optimize the microbial community, 3) evaluating environmental implications of constructed wetlands on soils that have little similarity to naturally occurring wetlands, 4) improved selection criteria for native vegetation that is appropriate for that climate and region, and 5) criteria to reapply treated water, especially for region's experiencing water deficiencies.

\section{Conflicts of Interest}

The authors declare that they have no conflict of interest.

\section{References}

Ali, Z., Mohammad, A., Riazb, Y., Quraishia, U. M., \& Malik, R. N. (2018). Treatment Efficiency of a Hybrid Constructed Wetland System for Municipal Wastewater and Its Suitability for Crop Irrigation. International Journal of Phytoremediation, 20, 1152-1161. https://doi.org/10.1080/15226514.2018.1460311

Assefa, R., Bai, R., \& Leta, S. (2019). Nitrogen Removal in Integrated Anaerobic-Aerobic Sequencing Batch Reactors and Constructed Wetland System: A Field Experimental Study. Applied Water Science, 9, 136. https://doi.org/10.1007/s13201-019-1015-8

Bai, S., Tao, V., Ding, Y., Li, X., You, S., Xie, Q., \& Brix, H. (2016). Multilayer Substrate Configuration Enhances Removal Efficiency of Pollutants in Constructed Wetlands. Water, 8, 556. https://doi.org/10.3390/w8120556

Carvalho, P. N., Arias, C. A., \& Brix, H. (2017). Constructed Wetlands for Water Treatment: New Developments. Water, 9, 397. https://doi.org/10.3390/w9060397

Chavan, P. V., \& Dennett, K. E. (2008). Wetland Simulation Model for Nitrogen, Phosphorus, and Sediments Retention in Constructed Wetlands. Water Air Soil Pollution, 187, 109-118. https://doi.org/10.1007/s11270-007-9501-2

Erler, D., \& Eyre, B. (2010). Quantifying Nitrogen Process Rates in a Constructed Wetland Using Natural Abundance Stable Isotope Signatures and Stable Isotope Amendment Experiments. Journal of Environmental Quality, 39, 2191-2199.

https://doi.org/10.2134/jeq2010.0067

Essington, M. (2004). Soil and Water Chemistry: An Integrated Approach. Boca Raton, FL: CRC Press. https://doi.org/10.1201/b12397

Hang, Q., Wang, H., Chu, Z., Ye, B., Li, C., \& Hou, Z. (2016). Application of Plant Carbon Source for Denitrification by Constructed Wetland and Bioreactor: Review of Recent Development. Environmental Science and Pollution Research, 23, 8260-8274.

https://doi.org/10.1007/s11356-016-6324-y

Huang, L., Gao, X., Guo, J., Ma, X., \& Liu, M. (2013). A Review on the Mechanism and Affecting Factors of Nitrous Oxide Emission in Constructed Wetlands. Environmental Earth Sciences, 68, 2171-2180. https://doi.org/10.1007/s12665-012-1900-Z

Hughes, W. B., Kown, S. R., \& Payne, V. W. E. (1996). Economic Assessment of Animal Waste Management Systems with a Constructed Wetland Component. In Proc. of the 
National Animal Waste Constructed Wetlands Conference (pp. 5-12). Ft. Worth, TX: Texas A \& M University Press.

Hunt, P. G., Matheny, T. A., \& Szogi, A. A. (2003). Denitrification in Constructed Wetlands Used for Treatment If Swine Wastewater. Journal of Environmental Quality, 32, 727-735. https://doi.org/10.2134/jeq2003.7270

Jesus, J. M., Danko, A. S., Fiuzal, A., \& Borges, M.-T. (2018). Effect of Plants in Constructed Wetlands for Organic Carbon and Nutrient Removal: A Review of Experimental Factors Contributing to Higher Impact and Suggestions for Future Guidelines. Environmental Science and Pollution Research, 25, 4149-4164. https://doi.org/10.1007/s11356-017-0982-2

Jia, Z., Tang, W., Luo, W., \& Hai, Y. (2016). Water Quality Improvement through Five Constructed Serial Wetland Cells and Its Implication on Nonpoint-Source Pollution Control. Hydrological Sciences Journal, 61, 2946-2956. https://doi.org/10.1080/02626667.2016.1171323

Kumar, S., \& Dutta, V. (2019). Constructed Wetland Microcosms as Sustainable Technology for Domestic Wastewater Treatment: An Overview. Environmental Science and Pollution Research, 26, 11662-11673. https://doi.org/10.1007/s11356-019-04816-9

Lu, S., Zhang, P., Jin, X., Xiang, C., Gui, M., Zhang, J., \& Li, F. (2009). Nitrogen Removal from Agricultural Runoff by Full-Scale Constructed Wetland in China. Hydrobiologia, 621, 115-126. https://doi.org/10.1007/s10750-008-9636-1

Meers, E., Tack, F. M. G., Tolpe, I., \& Michels, E. (2008). Application of a Full-Scale Constructed Wetland for Tertiary Treatment of Piggery Manure: Monitoring Results. Water Air Soil Pollution, 193, 15-24. https://doi.org/10.1007/s11270-008-9664-5

Miller, B. K., DuBowy, P. J., \& Reaves, R. P. (1996). Getting the Word out to Producers: Extension Ideas, Potential Approaches, and Activities. In Proc. of the National Animal Waste Constructed Wetlands Conference (pp. 43-52). Ft. Worth, TX: Texas A \& M University Press.

Munoz, M. A., Rosales, R. M., Gabarron, M., Faz, A., \& Scosta, J. A. (2016). Effects of Hydraulic Retention Time on Pig Slurry Purification by Constructed Wetlands and Stabilization Ponds. Water Air Soil Pollution, 205, 323-332. https://doi.org/10.1007/s11270-016-2993-X

Ouyang, Y. (2013). Effects of a Constructed Wetland and Pond System upon Shallow Groundwater Quality. Environmental Monitoring and Assessment, 185, 4245-4259. https://doi.org/10.1007/s10661-012-2865-9

Payne, V. W. E., Knight, R. L., \& Kown, S. R. (1996). A Holistic Approach to the Design of Constructed Wetlands for Treating Animal Wastes. In Proc. of the National Animal Waste Constructed Wetlands Conference (pp. 22-30). Ft. Worth, TX: Texas A \& M University Press.

Payne, V., \& Knight, R. (1997). Constructed Wetlands for Animal Waste Treatment. https://nepis.epa.gov/Exe/ZyPDF.cgi/200054US.PDF?Dockey=200054US.PDF

Reedyk, S., Zoski, E., Haaland, E., \& Tanko, H. (2017). Management of Runoff Wastewater from Confined Livestock Winter Feeding Sites: A Review of Treatment Technologies. Science and Technology Branch, Agriculture and Agri-Food Canada.

Scholz, M., \& Hedmark, A. (2010). Constructed Wetlands Treating Runoff Contaminated with Nutrients. Water Air Soil Pollution, 205, 323-332. https://doi.org/10.1007/s11270-009-0076-y

Sigua, G. C., Kang, W.-J., \& Coleman, S. W. (2006). Soil Profile Distribution of Phosphorus and Other Nutrients Following Wetland Conversion to Beef Cattle Pasture. Journal 
of Environmental Quality, 35, 2374-2382. https://doi.org/10.2134/jeq2006.0092

Tai, Y., Tam, N. F.-Y., Wang, R., Yang, Y., Lin, J., Wang, J., Yang, Y, Li, L., \& Sun, Y. (2018). Iron Plaque Formation on Wetland-Plant Roots Accelerates Removal of Water-Borne Antibiotics. Plant Soil, 433, 323-338. https://doi.org/10.1007/s11104-018-3843-y

Thalla, A. K., Devatha, C. P., Anagh, K., \& Sony, E. (2019). Performance Evaluation of Horizontal and Vertical Flow Constructed Wetlands as Tertiary Treatment Option for Secondary Effluents. Applied Water Science, 9, 147.

https://doi.org/10.1007/s13201-019-1014-9

United States Department Agriculture, Natural Resources Conservation Service (2009). Constructed Wetlands, Chapter 3. Part 637 Environmental Engineering National Engineering Handbook.

https://directives.sc.egov.usda.gov/OpenNonWebContent.aspx?content=25905.wba

USEPA (1995). Guide Manual on NPDES Regulations for Concentrated Animal Feeding Operations. EPA 833-B-95-001, Washington DC.

Wang, P., Zhang, H., Zuo, J., Zhao, D., Zou, X., Zhu, Z., Jeelani, N., Leng, X., \& An, S. (2016). Hardy Plant Facilitates Nitrogen Removal via Microbial Communities in Subsurface Flow Constructed Wetlands in Winter. Scientific Reports, 6, Article No. 33600. https://doi.org/10.1038/srep33600

Wang, Q., Hu, Y., Xie, H., \& Yang, Z. (2018). Constructed Wetlands: A Review on the Role of Radial Oxygen Loss in the Rhizosphere by Macrophytes. Water, 10, 678. https://doi.org/10.3390/w10060678

White, S. A. (2013). Wetland Technologies for Nursery and Greenhouse Compliance with Nutrient Regulations. HortScience, 48, 1103-1108. https://doi.org/10.21273/HORTSCI.48.9.1103

Yuan, C., Huang, T., Zhao, X., \& Zhao, Y. (2020). Numerical Models of Subsurface Flow Constructed Wetlands: Review and Future Development. Sustainability, 12, 3498. https://doi.org/10.3390/su12083498 